\title{
Penguatan Financiall Literacy dan Manajemen SDM Pada Industri Ekonomi Kreatif Berbasis Komunitas Wirausaha
}

\author{
Tatik$^{1}$, Maisaroh², Selfira Salsabilla ${ }^{3 *}$, Muhammad Khalifah Al Hakim ${ }^{4}$ \\ 1,3,4Program Studi Diploma 3 Akuntansi, Fakultas Bisnis dan Ekonomika, Universitas Islam Indonesia, \\ Yogyakarta, Indonesia \\ 2Program Studi Diploma 3 Manajemen, Fakultas Bisnis dan Ekonomika, Universitas Islam Indonesia, \\ Yogyakarta, Indonesia \\ *Corresponding author: selfirasalsabilla@uii.ac.id
}

\section{Abstrak}

Tujuan diselenggarakannya kegiatan pengabdian ini untuk mengatasi kendala yang dihadapi oleh pelaku usaha yang tergabung dalam komunitas Global Enterpreuneur Profesional (GENPRO) Kedu-DIY. Secara umum permasalahan yang terjadi pada usaha anggota Genpro DIY-Kedu adalah minimnya keahlian pengelolaan keuangan usaha, tidak adanya pembukuan usaha, pengalaman manajerial dan pengelolaan SDM yang sangat terbatas. Atas kendala yang dihadapi oleh pelaku usaha tersebut, tim pengabdian memberikan pemahaman serta pendampingan kepada anggota Genpro DIY - Kedu terkait financial literacy dan manejemen SDM. Metode pengabdian yaitu pelatihan dan pendampingan berkala yang intensif kepada para peserta. Melalui pemahaman dan implementasi yang tepat terkait financial literacy dan manajemen SDM, diharapkan usaha peserta mampu berkembang dalam jangka panjang dan juga meneladani nilai-nilai Islam dalam profesinalisme bekerja.

Kata kunci: financial literacy; manajemen SDM; UMKM

\section{Abstract}

The purpose of holding this service activity is to overcome the obstacles faced by business actors who are members of the Global Entrepreneur Professional Community (GENPRO) KeduDIY. In general, the problems that occur in the businesses of Genpro DIY-Kedu members are the lack of expertise in business financial management, the absence of business books, managerial experience and very limited human resource management. For the obstacles faced by these business actors, the service team provided understanding and assistance to members of Genpro DIY - Kedu related to financial literacy and HR management. The method of service is intensive periodical training and mentoring for the participants. Through proper understanding and implementation related to financial literacy and HR management, it is hoped that the participants' businesses will be able to develop in the long term and also imitate Islamic values in working professionalism.

Keywords: financial literacy; HR management; $M S M E$

Cite this article: Tatik., Maisaroh., Salsabilla, S., \& Al Hakim, M. K. (2021). Penguatan Financial Literacy dan Manajemen SDM Pada Industri Ekonomi Kreatif Berbasis Komunitas Wirausaha. Rahmatan Lil'alamin Journal of Community Services, 1 (1).

\section{Pendahuluan}

Sektor ekonomi merupakan salah satu sektor yang terdampak dengan adanya pandemic Covid-19. Tak terkecuali berdampak pada pelaku Usaha Mikro, Kecil, dan Menengah (UMKM) di Indonesia. Pilar utama dalam 
perekonomian Indonesia adalah UMKM. Berdasarkan data Kementerian Koperasi dan UKM, jumlah UMKM saat ini mencapai 64,2 juta dengan kontribusi terhadap PDB sebesar $61,07 \%$ atau senilai 8.573,89 triliun rupiah. Kontribusi UMKM terhadap perekonomian Indonesia meliputi kemampuan menyerap $97 \%$ dari total tenaga kerja yang ada serta dapat menghimpun sampai $60,4 \%$ dari total investasi (Limanseto, 2021). Namun, muncul tantangan baru yang harus dihadapi oleh pelaku UMKM. Berbagai permasalahan harus dihadapi oleh UMKM dalam pengelolaan bisnisnya. Masih banyak ditemukan pelaku UMKM di Indonesia yang tidak membuat dan memakai informasi akuntansi dalam pengelolaan usahanya (Widiastoeti \& Sari, 2020). Minimnya SDM yang memiliki pengetahuan tentang proses akuntansi membuat pelaku UMKM kesulitan dalam melakukan pencatatan transaksi di perusahaan (Widiastoeti \& Sari, 2020). Selain itu, permasalahan yang biasa dihadapi oleh UMKM dan menjadi kelemahannya adalah minimnya tata kelola manajemen Sumber Daya Manusia (SDM) dalam kelompok dan pengelolaan administrasi yang belum memadai (Naufalin, 2020). Terdapat beberapa masalah yang juga dihadapi oleh UKM terkait dengan belum matangnya proses dimulai dari, pengadaan, perencanaan, produksi, dan pengiriman (Yusrianafi \& Dahda, 2021).

Permasalahan yang dihadapi oleh UMKM pada umumnya juga terjadi pada anggota Genpro (Global Enterpreuneur Profesional). Genpro adalah komunitas pengusaha yang memiliki jaringan di 34 Provinsi dan 200 Kabupaten Kota yang ada di Indonesia. Salah satu jaringannya adalah Genpro Daerah Istimewa Yogyakarta (DIY)-Kedu yang dibentuk untuk membangun dan memberdayakan UMKM di wilayah DIY dan Kedu. Genpro DIY - Kedu memiliki 11 Chapter, yaitu Chapter Sleman, Chapter Kota Yogyakarta, Chapter Kulon Progo, Chapter Bantul, Chapter Gunung Kidul, Chapter Kabupaten Magelang, Chapter Kota Magelang, Chapter Temanggung, Chapter Wonosobo, Chapter Purworejo, dan Chapter Kebumen.

Jumlah anggota Genpro DIY- Kedu berkisar 850 orang. Mayoritas anggota adalah pengusaha dengan kriteria usaha mikro, dan sebagian lagi pada kriteria usaha kecil. Hanya beberapa saja yang merupakan pengusaha dengan kriteria usaha menengah. Adapun kriteria usaha anggota Genpro DIY - Kedu mengacu pada PP Nomor 7 Tahun 2021 seperti dalam tabel 1.

Tabel 1. Kriteria UMKM

\begin{tabular}{llll}
\hline No & \multicolumn{1}{c}{ Uraian } & \multicolumn{1}{c}{ Modal } & \multicolumn{1}{c}{ Hasil Penjualan } \\
\hline 1 & Usaha Mikro & Maks. 1 miliar & Maks. 2 miliar \\
2 & Usaha Kecil & $>1$ miliar -5 miliar & $>2$ miliar -15 miliar \\
3 & Usaha Menengah & $>5$ miliar -10 miliar & $>15$ miliar -50 miliar \\
\hline
\end{tabular}

Sumber : https://jdih.setkab.go.id/

Pengelolaan keuangan adalah salah satu diantara permasalahan utama yang dihadapi dalam mengembangkan UMKM (Selvi, 2021). Secara umum permasalahan tersebut juga terjadi pada usaha anggota Genpro DIY - Kedu yaitu minimnya keahlian pengelolaan keuangan usaha, tidak adanya pembukuan usaha, pengalaman manajerial, dan pengelolaan sumber daya manusia (SDM) yang sangat terbatas. Permasalahan tersebut hampir sama yang dialami oleh pelaku usaha pada level Mikro, Kecil dan Menengah. 
Sementara ini pendampingan usaha yang telah dilakukan oleh mentor, lebih banyak menyentuh sektor pemasaran, produksi, dan operasional. Sehingga pendampingan dalam hal financial literacy dan manajemen SDM sangat dibutuhkan untuk menguatkan usaha para anggota.

Urgensi dilakukannya pengabdian masyarakat ini terletak pada usaha atau bisnis yang dijalankan tanpa pengelolaan keuangan yang baik, akan menimbulkan banyak permasalahan keuangan. Pada sektor Usaha Mikro, Kecil dan Menengah, pengelolaan keuangan sangat diperlukan terutama untuk berlatih profesional memisahkan keuangan pribadi dan bisnis. Selain itu, pembukuan sederhana juga diperlukan UMKM untuk mengevaluasi perkembangan usaha dan menganalisis keputusan yang tepat dalam rangka pengembangan usaha. Adanya laporan keuangan juga akan membantu pemilik untuk mengetahui keuntungan yang diperoleh, mengetahui tambahan modal yang dicapai, dan mengetahui keseimbangan hak dan kewajiban yang dimiliki (Selvi, 2021). Namun seringkali pelaku UMKM menganggap bahwa ilmu akuntansi dan laporan keuangan itu sulit dan hanya bisa dipelajari oleh mahasiswa atau orang yang sekolah tinggi saja (Hairunisa \& Subiyantoro, 2017).

Selain itu, pengelolaan SDM agar entitas usaha dapat mencapai target yang ditetapkan juga sangat diperlukan oleh anggota Genpro DIY - Kedu. Tenaga kerja SDM sebagai faktor produksi mempunyai arti yang besar. Karena semua kekayaan alam tidak berguna jika tidak dieksploitasi oleh manusia. Oleh karena itu setiap perusahaan seharusnya sangat memperhatikan SDM sebagai salah satu faktor produksi (Suripto, 2012).

Mengingat SDM pada usaha anggota Genpro - DIY masih terbatas sehingga harus dikelola seefisien mungkin agar tidak terjadi tumpang tindih tugas yang berujung pada lemahnya kontrol terhadap proses bisnisnya. Berdasarkan uraian di atas, kegiatan pengabdian ini mengusulkan topik Penguatan Financial Literacy dan Manajemen SDM Pada Industri Ekonomi Kreatif Berbasis Komunitas Wirausaha.

\section{Metode Pelaksanaan}

Metode pelaksanaan kegiatan pengabdian masyarakat mengenai financial literacy dan manajemen SDM dilakukan melalui beberapa tahap kegiatan. Gambar 1 menyajikan rincian kegiatan setiap tahap. Beberapa kegiatan yang bisa dilakukan dengan mempertimbangkan peluang, potensi dan berdasarkan pada identifikasi permasalahan adalah sebagai berikut:

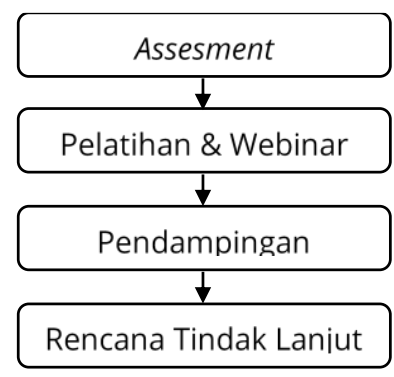

Gambar 1. Metode Pelaksanaan Kegiatan Pengabdian 


\section{Assesment}

Pada proses assessment ini pengabdi melakukan diskusi bersama pengurus dan anggota Genpro DIY - Kedu terkait kebutuhan anggota dalam rangka menguatkan dan mengembangkan usaha. Target dari assessment ini adalah mendapatkan data profil usaha anggota Genpro DIY - Kedu, permasalahan secara umum, pencatatan atau pembukuan keuangan (jika ada) dan data lain terkait usaha anggota insitusi mitra. Proses assessment dilakukan pada perwakilan usaha anggota institusi mitra yang mewakili tiap chapter dari 11 chapter. Adapun perwakilan yang diajak berdiskusi merupakan usaha yang ditunjuk oleh pengurus Genpro DIY - Kedu, sesuai dengan kriteria yang diusulkan pengabdi, yaitu mewakili usaha dengan kriteria usaha mikro, usaha kecil dan usaha menengah.

\section{Pelatihan dan Webinar}

Pelatihan diikuti oleh 25 anggota Genpro DIY - Kedu perwakilan dari 11 chapter. Pelatihan terdiri dari dua topik, yaitu financial literacy dan manajemen SDM. Pelatihan financial literacy akan dibagi menjadi 2 pelatihan, yaitu: Pengelolaan Keuangan pada UMKM yang berfokus pada mental kaya, prinsip dasar pengelolaan keuangan usaha, memahami profit dan cash, profesional menggaji diri, dan pembagian pos keuntungan usaha dan Pembukuan Sederhana untuk UMKM dimana peserta akan menyusun pembukuan sederhana secara praktis dan sesuai dengan Standar Akuntansi Keuangan Entitas Mikro Kecil dan Menengah (SAK EMKM).

Adapun pelatihan Manajemen SDM terdiri dari Penyusunan Key Performance Indicator (KPI) dan Penyusunan Standart Operational Procedure (SOP). Dalam pelatihan ini, peserta akan diberikan pengetahuan tentang KPI dan Langkah mudah menyusunnya, yaitu review tugas inti/uraian pekerjaan individu, review tugas project, analisa dan sinergi tahap 1 dan 2 serta merancang sasaran kinerja, menentukan KPI dan bobotnya, dan target KPI. Peserta juga akan diberikan pengetahuan tentang SOP dan langkah mudah menyusunnya, meliputi membentuk tim penyusun SOP, mempelajari proses bisnis, menyusun prosedur kerja, menyusun alur kerja, simulasi SOP, evaluasi dan perbaikan, fixasi SOP, dan sosialisasi SOP.

Selain pelatihan financial literacy dan manajemen SDM, tim juga membuat program pendalaman materi melalui rangkaian webinar. Webinar tersebut disampaikan oleh praktisi professional dibidangnya. Pelaksanaan webinar ini dilaksanakan secara daring.

3. Pendampingan

Setelah dilakukan pelatihan, peserta mendapatkan pendampingan sekitar 3 bulan, dengan mekanisme 1x pendampingan tiap bulan. Pendampingan dilakukan dengan metode coaching, dimana para peserta diajak berdiskusi untuk mencari solusi atas permasalahan di bisnis masing-masing. Agar pendampingan dapat optimal, 25 peserta dibagi dalam beberapa kelompok, satu kelompok terdiri dari 3-4 orang. Peserta diminta menyampaikan capaian target saat pelatihan, baik pada sisi keuangan maupun SDM. Peserta juga diizinkan untuk mendiskusikan 
berbagai masalah dan hambatan yang dialami dalam implementasi di unit usahanya.

4. Rencana Tindak Lanjut

Pengabdian ini diharapkan tidak berakhir setelah masa pendampingan selesai, yaitu selama 6 bulan. Peserta pengabdian yang terdiri dari 25 anggota Genpro DIY - Kedu diharapkan mampu membagikan ilmu dan skill yang didapatkan kepada anggota lainnya di masing-masing chapter. Pengurus Genpro DIY - Kedu dapat memonitor tindak lanjut kegiatan melalui ketua dari masing-masing chapter. Bentuk kegiatan dapat disesuaikan dengan sumber daya chapter masing-masing, misalnya sharing season, pelatihan singkat atau kegiatan lainnya.

Kegiatan pengabdian ini akan melibatkan dosen prodi Diploma III Akuntansi dan Manajemen FBE UII, pengurus Genpro DIY-Kedu, pelatih professional, dan perwakilan dari anggota Genpro DIY-Kedu. Pelaksanaan kegiatan pengabdian berlangsung selama 6 bulan yang dilaksanakan secara tatap muka dan daring. Pelaksanaan tatap muka dibagi menjadi 2 tahap. Tahap pertama pelatihan manajemen SDM diselenggarakan di Rumah Makan Bu Baha, Jalan Garuda, Plumbon, Bantul pada tanggal 18 dan 19 Maret 2021. Tahap kedua pelatihan financial literacy diselenggarakan di Hotel Grand Serela, Jalan Magelang pada tanggal 29 dan 30 Maret 2021. Pelaksanaan daring terkait pendampingan pasca pelatihan dilaksanakan selama bulan April hingga Agustus 2021.

\section{Pembahasan}

Kegiatan ini bertujuan untuk memberikan keterampilan dan keahlian dalam pengelolaan keuangan dan manajemen SDM. Sebelum pelaksanaan kegiatan pengabdian masyarakat, dilakukan proses assessment yang dilakukan oleh tim pengabdian dengan pengurus dan anggota Genpro DIYKedu terkait kendala yang dihadapi oleh anggota dalam pengelolaan bisnisnya. Dari hasil diskusi tersebut secara umum terdapat 2 kendala utama, yaitu pencatatan/pembukuan keuangan dan pengelolaan SDM. Dengan latar belakang kendala tersebut, maka tim pengabdian membentuk kegiatan pelatihan dan pendampingan. Kegiatan pendampingan masyarakat ini dilakukan dalam beberapa tahapan sebagai berikut:

\section{Pelatihan Manajemen SDM}

Pada kegiatan pelatihan manajemen SDM, terbagi menjadi beberapa sub aktivitas pemaparan materi. Pada hari pertama, materi disampaikan oleh Bapak Ryan Martin selaku pelatih professional menjelaskan terkait perancangan rencana strategis dan pengelolaan kinerja bisnis. Pada hari kedua, pemateri melanjutkan pemaparan materi terkait penyusunan dan pengidentifikasian $\mathrm{KPI}$, serta perancangan SOP/strategi map in corporate function. Dari hasil pemaparan 2 hari tersebut diharapkan para serta mampu menyusun KPI dan SOP untuk masing-masing usahanya. Gambar 2 menyajikan gambar kegiatan penyampaian materi manajemen SDM. 


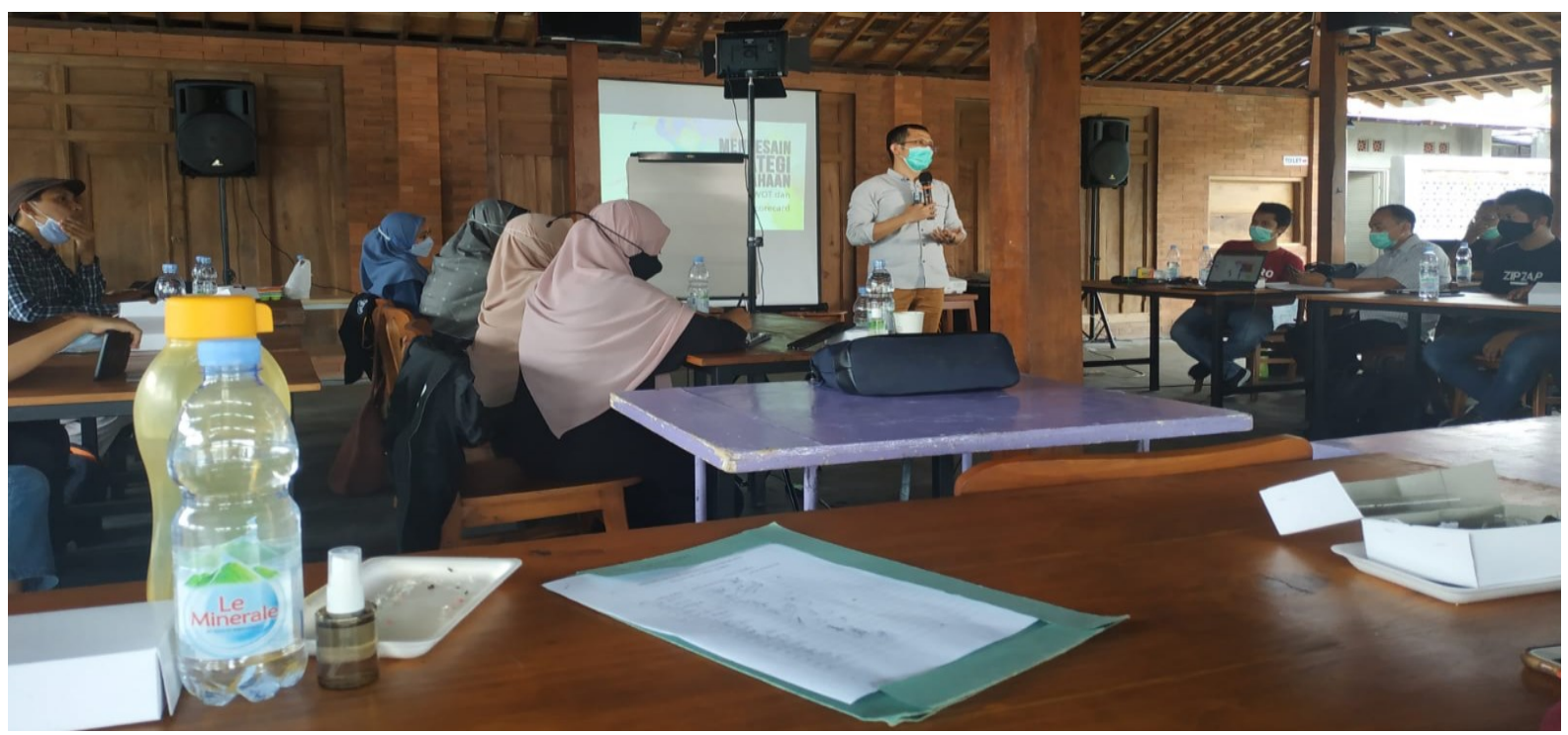

Gambar 2. Kegiatan pemaparan materi manajemen SDM

\section{Pelatihan Financial Literacy}

Pelatihan financial literacy merupakan lanjutan dari serangkaian kegiatan pengabdian yang telah disusun oleh tim. Kegiatan ini dilakukan selama 2 hari pada tanggal 29 dan 30 Maret 2021. Kegiatan tersebut dilaksanakan di Hotel Grand Serela, Jalan Magelang sesuai dengan protokol kesehatan yang berlaku. Hari pertama, peserta diberikan pemaparan materi yang disampaikan oleh lbu Tatik, SE., M.Ak., CA. selaku perwakilan dari dosen Diploma III Akuntansi FBE UII. Materi yang disampaikan diawali dengan penjelasan pronsip dasar pengelolaan keuangan bisnis, menghitung harga pokok penjualan dan target penjualan, menghitung titik impas, dan diakhiri dengan sesi penyusunan laporan keuangan dan analisa laporan keuangan. Pada hari kedua, peserta mulai mencoba untuk menyusun laporan keuangan dan melakukan analisis atas laporan keuangan usahanya. Pada kegiatan praktik ini peserta didampingi oleh tim pengabdian. Gambar 3 menyajikan gambar pemaparan materi financial literacy.

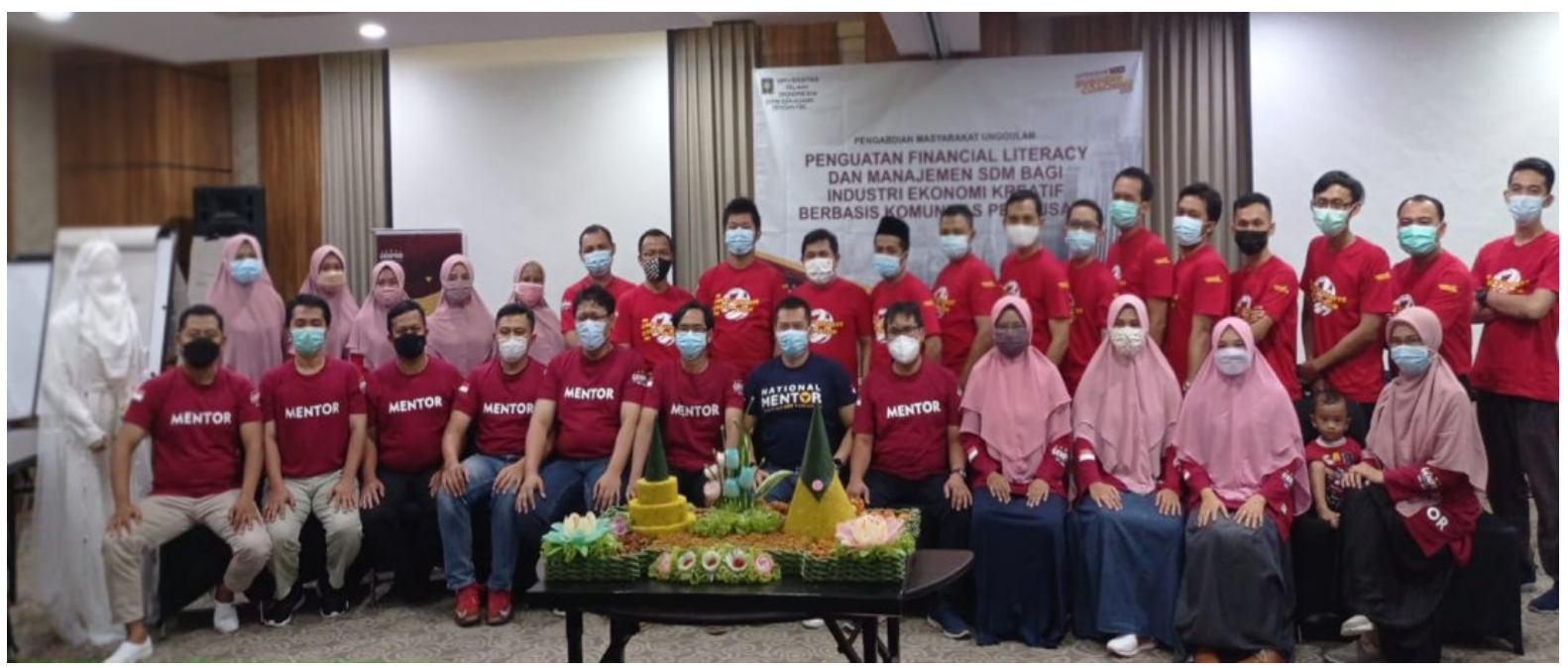

Gambar 3. Kegiatan pemaparan materi financial literacy 
3. Festival Webinar

Kegiatan festival webinar ini merupakan kegiatan lanjutan untuk memberikan penguatan materi bagi peserta mengenai financial literacy dan manajemen SDM. Webinar ini juga bertujuan untuk berbagi pengalaman antar peserta. Festival webinar ini dilaksanakan secara daring melalui aplikasi zoom. Adapun rangkaian pelaksanaan webinar tersaji dalam tabel 2.

Tabel 2. Rangkaian Festival Webinar

\begin{tabular}{|c|c|c|c|c|}
\hline No & Pemateri & Topik Webinar & $\begin{array}{c}\text { Tanggal } \\
\text { Pelaksanaan }\end{array}$ & $\begin{array}{c}\text { Durasi } \\
\text { Pelaksanaan }\end{array}$ \\
\hline 1 & $\begin{array}{l}\text { Fauzi Yulianto, owner } \\
\text { Brownies Cinta }\end{array}$ & Meraih Berkah dengan Syirkah & 21 April 2021 & $10.00-11.30$ \\
\hline 2 & $\begin{array}{l}\text { Yanti Wahyuni, S. Gz, owner } \\
\text { Hijab Qiyada }\end{array}$ & $\begin{array}{l}5 \text { Ways to Increase Your } \\
\text { Business Profit }\end{array}$ & 22 April 2021 & $10.00-11.30$ \\
\hline 3 & $\begin{array}{l}\text { M. Manar Barmawi, SE, Ak, } \\
\text { M. Ak, CA, CMA, CPA (Aust), } \\
\text { CRP, PFM, praktisi dan } \\
\text { akademisi }\end{array}$ & Mari Belajar Investasi & 27 April 2021 & $10.00-11.30$ \\
\hline 4 & $\begin{array}{l}\text { Hasnil Afrizal Muttaqin, ST, } \\
\text { owner Eka Farm }\end{array}$ & Manajemen Free Cash & 29 April 2021 & $10.00-11.30$ \\
\hline 5 & Alim Mahdi, CPHCM & Standart Operating Procedures & 3 Mei 2021 & $10.00-11.30$ \\
\hline 6 & $\begin{array}{l}\text { Andi Susilo, owner } \\
\text { Elhurriyah Fashion }\end{array}$ & Pentingnya Mengelola Profit & 4 Mei 2021 & $10.00-11.30$ \\
\hline
\end{tabular}

\section{Coaching Pasca Pelatihan}

Pendampingan pasca pelatihan merupakan tahapan berikutnya dalam program pengabdian. Pelaksanaan pendampingan berlangsung selama bulan April hingga Agustus 2021. Program pendampingan ini berfungsi untuk memfasilitasi para peserta jika mengalami kendala dalam menyusun laporan keuangan, membuat SOP, dan KPI. Pada kegiatan ini dipilih 8 orang mentor yang bertanggung jawab untuk mendampingi 3 hingga 4 peserta. Kegiatan dilaksanakan minimal sebulan sekali dengan jadwal yang disepakati antara mentor dan peserta. Tema yang dibahas mengalir sesuai kebutuhan dan masalah bisnis peserta, namun secara garis besar terfokus pada business owner mentality, SDM, akuntansi, keuangan, marketing dan produksi.

5. Rencana Tindak Lanjut

Rencana tindak lanjut adalah tahapan kelanjutan dimana setelah peserta diberikan pelatihan, webinar, dan pendampingan, tim pengabdi memantau kinerja masing-masing peserta melalui ketua dari masingmasing chapter. Sebanyak 21 peserta telah mampu memisahkan keuangan pribadi dengan usaha dan menyusun SOP untuk usahanya. 20 peserta sudah mampu membuat KPI untuk menilai kinerja usahanya dan 17 peserta telah menyusun laporan keuangan usahanya. 


\section{Kesimpulan}

Kegiatan pengabdian untuk memperkuat financial literacy dan pengelolaan SDM diikuti sebanyak 25 pelaku usaha yang tergabung dalam Genpro DIYKedu yang merupakan perwakilan dari 11 chapter. Pengabdian ini diawali dengan mengidentifikasi permasalah yang sebagian besar dihadapi oleh anggota Genpro DIY-Kedu, yaitu terkait pengelolaan keuangan usaha dan pengelolaan manajemen perusahaan. Dari permasalahan tersebut dipilih 2 topik yang dijadikan sebagai materi pelatihan, yaitu pelatihan financial literacy yang terdiri dari pengelolaan keuangan pada UMKM dan pembukuan sederhana untuk UMKM, serta pelatihan manajemen SDM yang terdiri dari penyusunan KPI dan penyusunan SOP. Setelah dilaksanakan pelatihan maka peserta akan mendapatkan pendampingan selama 3 bulan. Dari hasil akhir pendampingan diperoleh sebanyak $84 \%$ peserta mampu memisahkan pengelolaan keuangan pribadi dan usaha, $68 \%$ peserta telah memiliki laporan keuangan sesuai dengan standar SAK EMKM, 80\% peserta mampu menyusun KPI pada masing-masing bidang di unit usahanya, dan $84 \%$ peserta mampu menyusun SOP pada masing-masing bidang di unit usahanya.

Kegiatan pengabdian telah berjalan sesuai dengan target, namun terdapat beberapa kendala yang dihadapi yaitu kesibukan mentor dalam pendampingan. Setelah proses pelatihan, peserta akan melakukan pendampingan bersama mentor. Dimana seorang mentor akan bertanggungjawab pada 4-5 peserta binaan. Karena kesibukan yang dihadapi oleh mentor, maka terdapat kendala dalam memberikan umpan balik dari laporan yang sudah disiapkan oleh masing-masing peserta. Selain itu, sebanyak 32\% peserta masih kesulitan untuk dapat konsisten dalam menyusun laporan keuangannya karena keterbatasan waktu. Oleh sebab itu, diharapkan pengabdian kedepannya dapat menambah jumlah mentor, misalnya 1 mentor cukup memonitor 1 atau 2 peserta supaya lebih dapat fokus dalam mendampingi peserta. Pengabdian berikutnya diharapkan juga dapat mengenalkan beberapa aplikasi akuntansi berbasis smartphone, supaya proses pencatatan keuangan dapat lebih fleksibel karena dapat dengan mudah diakses melalui smartphone masing-masing peserta dan penggunaannya lebih mudah.

\section{Ucapan Terima Kasih}

Ucapan terima kasih disampaikan kepada Direktorat Penelitian dan Pengabdian Kepada Masyarakat (DPPM) Universitas Islam Indonesia yang telah mendanai program ini.

\section{Referensi}

Hairunisa, N., \& Subiyantoro, H. (2017). Kepada Pengusaha UMKM di Kacamatan Karangrejo Kabupaten Tulungagung. Jurnal Pengabdian Kepada Masyarakat, 4(2).

Limanseto, H. (2021). UMKM Menjadi Pilar Penting dalam Perekonomian 
Indonesia. Retrieved from

https://ekon.go.id/publikasi/detail/2969/umkm-menjadi-pilarpenting-dalam-perekonomian-indonesia

Naufalin, L. R. (2020). Tantangan Pengembangan Usaha Mikro Kecil dan Menengah (UMKM) di Kabupaten Banyumas. Jurnal Ekonomi, Bisnis, Dan Akuntansi, 22(1).

Peraturan Pemerintah Republik Indonesia Nomor 7 Tahun 2021 Tentang Kemudahan, Pelindungan, dan Pemberdayaan Koperasi dan Usaha Mikro, Kecil, Menengah

Selvi, E. (2021). Pelatihan Pengelolaan Pembukuan Dan Pelaporan Keuangan Bagi Pelaku UMKM Di Desa Kutakarya Karawang. Jurnal Pengabdian Kepada Masyarakat Bina Darma, 1(1).

Standar Akuntansi Keuangan Entitas Mikro, Kecil dan Menengah. 2016. Jakarta: Ikatan Akuntan Indonesia.

Suripto, T. (2012). Manajemen SDM dalam Perspektif Ekonomi Islam: Tinjauan Manajemen SDM dalam Indusri Bisnis. Jurnal Ekonomi Syariah Indonesia, 2(2).

Widiastoeti, H., \& Sari, C. A. E. (2020). Penerapan Laporan Keuangan Berbasis Sakemkm Terhadap Kualitas Laporan Keuangan Pada Umkm Kampung Kue Di Rungkut Surabaya. Jurnal Analisi, Predeksi, Dan Informasi, 21(1).

Yusrianafi, N., \& Dahda, S. S. (2021). Pengukuran Kinerja Pada UKM Kerudung Menggunakan Metode Supply Chain Operator Reference (SCOR) Dan AHP. Jurnal IImiah Mahasiswa Teknik Industri Universitas Kadiri, 3(2). 